\title{
Expression of Patched-1 Protein in Aggressive and Nonaggressive Basal Cell Carcinoma
}

\author{
Putu Marcelina $^{1}$, Alwi Mappiasse ${ }^{1}$, Anis Irawan Anwar ${ }^{1}$, Idham Jaya Ganda ${ }^{2,3}$, \\ Mohammad Hatta ${ }^{4}$, Rina Masadah ${ }^{5}$ \\ ${ }^{1}$ Department of Dermatology and Venereology, Medical Faculty, Hasanuddin University, Makassar, Indonesia \\ ${ }^{2}$ Department of Biostatistic, Faculty of Public Health, Hasanuddin University, Makassar, Indonesia \\ ${ }^{3}$ Department of Pediatrics, Medical Faculty, Hasanuddin University, Makassar, Indonesia \\ ${ }^{4}$ Department of Microbiology, Medical Faculty, Hasanuddin University, Makassar, Indonesia \\ ${ }^{5}$ Department of Anatomical Pathology, Medical Faculty, Hasanuddin University, Makassar, Indonesia
}

Email address:

marcyhartono@gmail.com (P. Marcelina)

\section{To cite this article:}

Putu Marcelina, Alwi Mappiasse, Anis Irawan Anwar, Idham Jaya Ganda, Mohammad Hatta, Rina Masadah. Expression of Patched-1 Protein in Aggressive and Nonaggressive Basal Cell Carcinoma. American Journal of Clinical and Experimental Medicine. Vol. 4, No. 5, 2016, pp. 122-128. doi: 10.11648/j.ajcem.20160405.12

Received: June 30, 2016; Accepted: July 30, 2016; Published: August 21, 2016

\begin{abstract}
Basal cell carcinoma (BCC) or basalioma, is a skin cancer characterized by slow-growing, minimal local invasion, rarely metastasize, but can result in extensive morbidity through local invasion and tissue destruction if the treatment was delayed. In this genomic era, aggressiveness of BCC mainly affected by intrinsic factor such as molecular biological dysregulation. The aim of this study was to assess the correlation between level of PTCH1 protein expression and aggressiveness of BCC histopathology. This study was an observational and cross-sectional study with analytical approach, conducted at Outpatient Clinic of Dermatology and Venereology Department of Dr. Wahidin Sudirohusodo Hospital Makassar, Hasanuddin University Hospital, Anatomical Pathology Laboratory of Dr. Wahidin Sudirohusodo and Hasanuddin University Hospital, and Sentra Diagnostic Patologia Laboratory, Makassar from September 2014 to January 2016. Total sample was 37 paraffin block evaluated and classified as aggressive and nonaggressive BCC by histopathological finding. Aggressive type BCCs were 34 samples $(91.9 \%)$ and nonaggressive type were 3 samples $(8.1 \%)$. Micronodular type was the most common histopathologic feature in 30 of 37 subjects (81.1\%) and 30 of 88 histopathological finding (34.1\%). Each subject can have more than one histopathologic type. Percentage of strong expression PTCH1 was found highest in pigmented type (33.4\%), the percentage of moderate expression PTCH1 was found highest in infiltrating type (60.0\%), and the percentage of negative/weak PTCH1 expression was found highest in the nodular type (75.0\%). In this study, the correlation between the aggressiveness and PTCH 1 expression was not significant statistically ( $>>0.05$ ), but it is seen that the frequency of strong PTCH1 expression was found to be higher in aggressive than nonaggressive BCC.
\end{abstract}

Keywords: Basal Cell Carcinoma, Patched-1, Aggressive, Nonaggressive

\section{Introduction}

Basal cell carcinoma (BCC), also called basalioma or rodent ulcer, is a skin cancer with characteristics of slowgrowing, minimal local invasion, rarely metastasize, but can result in extensive morbidity through local invasion and tissue destruction if the treatment was delayed. [1-5] This type of carcinoma primarily affects the elderly, white skin, mean age 60 years, locations mostly in areas exposed to sunlight, notably the face as much as $75 \%$. $[1,3,6]$ Basal cell carcinoma is common in Caucasian, $\mathrm{BCC}$ incident in the USA is increased significantly every year, while the highest incidence in the world are in Australia. [7] BCC incident on the Asian race is still lower than the Caucasian. Until recently, in Indonesia accurate data on the incidence of BCC is not yet determined, but studies in Palembang showed 
increased significantly since the last 15 years, Toruan (2000) found the incidence of BCC $0.042 \%$, Yahya (2008) reported $0.11 \%$ and in 2010 was $0.30 \%$. [8] Retrospective study by Marcelina et al (2014) at the Outpatient Clinic of Dermatology and Venereology Department of Dr. Wahidin Sudirohusodo Hospital Makassar in 2010 to 2014 found the number of BCC patient visit as much as $0.3 \%$. [9]

Until now, the mechanism of growth and development of BCC still a long controversy and debate. According to the theory, pathogenesis of $\mathrm{BCC}$ is influenced by extrinsic and intrinsic risk factors. Extrinsic risk factors especially sun exposure plays a major role in the development of BCC, but in the era of genomics today, aggressiveness BCC mainly affected by the intrinsic risk factors such as molecular biology dysregulation. [3, 5, 10]

Basal cell carcinoma cells derived from the pluripotential basal cell formed constantly throughout human life. In general, tumors derived from the epidermis, but can also grow from the outer root sheath of hair follicles. Carcinogenesis is a gradual and complex process of accumulation of genetic changes. In cancer etiopathogenesis there are four genes that play an important role: oncogenes, tumor suppressor genes, genes encoding apoptosis and DNA repair. [11] The most common genetic aberrations in human skin cancers are found at the level of the p53 gene. Radiation of ultraviolet rays cause DNA mutations in certain genes in the cell, such as the p53 gene for BCC and squamous cell cancer, and Patched-1 (PTCH1) gene for BCC. [12]

Various studies conducted to find the relationship between risk factors and aggressiveness of BCC. Most of the researchers found histopathology type of $\mathrm{BCC}$ based on a growth pattern, which is associated with dysregulation of molecular biology and prognosis, [5] classifies BCC as high risk / aggressive and low risk / nonaggressive. [1] Nonaggressive $\mathrm{BCC}$ is a low risk, non-invasive BCC, with surgical excision give satisfactory results, and the prognosis is good. This type includes nodular and superficial BCC type based on histopathology. Aggressive BCC is a high risk, invasive, tend to undergo recurrence with a range of $12 \%$, but based on histopathology, aggressive type of BCC tend to increase rapidly in recurrence with the range of $65 \%$, and strongly correlated significantly with the invasion and infiltration into surrounding tissues subclinically, increased morbidity with a poor prognosis. [1]

Extensive evidence implicates Sonic Hedgehog ( $\mathrm{SHH}$ ) in the tumorigenesis of BCC. Sonic hedgehog is a highly conserved gene coding for a signaling protein that plays a major role in the development of the nervous and skeletal systems, and malfunction is linked to the occurrence of various tumors. Abnormal hedgehog signaling is found in sporadic and familial BCC, medulloblastoma, rhabdomyosarcoma, and other malignancies. [13-15]

Dysfunction of this pathway is due to either mutations in SHH or alteration of related signaling elements such as Patched (PTCH) and Smoothened (SMO). Patched (PTCH) is a 12-pass transmembrane protein whose activity is inhibited by its ligand, the $\mathrm{SHH}$ protein. Patched $(\mathrm{PTCH})$ acts as a tumor suppressor by inhibiting the activity of the 7-pass transmembrane protein SMO through an indirect catabolic mechanism. Although mutations in SHH itself are relatively rare, genetic changes in $\mathrm{PTCH}$ and SMO tend to be far more common. Studies over the past few years have linked specifically the loss of heterozygosity ( $\mathrm{LOH}$ ) of PTCH to development of BCC. Interestingly, the tumor suppressor PTCH gene maps to this exact location on chromosome $9 \mathrm{q}$. Data on LOH in sporadic BCCs at chromosome 9q22 have been found to range from $30 \%$ to $90 \%$ and $\mathrm{LOH}$ has been implicated in the involvement of the PTCH gene in the tumorigenesis of BCC. Pilot studies conducted by Fernandes et al (2010) found that loss of heterozygosity on chromosome $9 \mathrm{q} 22$ that encodes a PTCH1 gene is marker to identify the potential aggressiveness of BCC. [13]

Some reports have indicated that aggressive BCC positively correlated with the expression of p53 and negatively correlated with protein expression of antiapoptotic BCL-2. [1]

This study aims to assess the expression of Patched-1 protein (PTCH1) in BCC aggressive and nonaggressive. So far, no studies had compared the PTCH1 protein expression by immunohistochemistry in aggressive and nonaggressive BCC. Researchers also assesed the PTCH1 expression in various histopathology type. This research is expected to determine the nature of the $\mathrm{PTCH} 1$ protein expression in predicting the aggressiveness of BCC. Thus, it can help in the selection of appropriate therapies and predicting the prognosis of patients with $\mathrm{BCC}$.

\section{Material and Methods}

\subsection{Study Design and Patient Specimens}

This study was an observational and cross-sectional study with analytical approach, conducted on skin biopsies of patients with $\mathrm{BCC}$, presenting to Outpatient Clinic of Dermatology and Venereology Department of Dr. Wahidin Sudirohusodo Hospital Makassar and Hasanuddin University Hospital from 2010-2015, where their biopsy samples were referred to Anatomical Pathology Laboratory of Dr. Wahidin Sudirohusodo and Hasanuddin University Hospital, as well as Sentra Diagnostic Patologia Laboratory, Makassar, Indonesia. This study was conducted from September 2014 to January 2016. Total sample was 37 paraffin blocks evaluated and classified as aggressive and nonaggressive BCC by histopathological finding. The criteria of for the nonaggressive BCCs were nodular, superficial, pigmented, infuncibulocystic, adenoid subtype without perineural or perivascular invasion. The aggressive BCCs were those with the subtype such as infiltrating, micronodular, morpheaform, metatypical, and basosquamous, with perineural or perivascular invasion.

\subsection{Immunohistochemistry of PTCH1}

All tissue samples were paraffin-embedded and formalinfixed for immunohistochemistry (IHC) evaluation for 
PTCH1. Then tissue cuts were prepared in $4 \mu \mathrm{m}$ thick using Leica 2125 RM microtom and placed on glassy slides. The used glasses were coated by poly-L-lysine. The slides were heated on hotplate then put into the incubator $30-40^{\circ} \mathrm{C}$ for 1 hour until dried. Then the samples were deparaffinized and put into xylol solution three times for 5 minutes each, rinse in the ethanol and alcohol $90 \%, 80 \%$, and $70 \%$ for 5 minutes each, the wash with distilled water. Inactivation of endogenous peroxidase using 3\% hydrogen peroxide and methanol for 15 minutes, rinse with aquadest for 5 minutes. Then, rinse in the antigen target retrieval solution and put into microwave for 30 minutes, then wash with aquadest. Drop the block protein sniper for 30 minutes, rinse with phosphate buffer saline (PBS) for 5 minutes. Then drop the primary anti-PTCH1 (clone 5C7) monoclonal antibody from LSBio for 1 hour, rinse with PBS. For the secondary antibody, drop the biotinylated goat anti-polyvalent for 30 minutes, rinse with PBS. Drop the streptavidine-biotin for 20 minutes, rinse again with PBS twice for 5 minutes each. After staining, the slices were put in 3, 3-diaminobenzidine (DAB) and chromogen substrate which lead to detection of antigen with brown color, then rinse with distilled water. Counterstaining with Mayer haematoxyllin for 2 minutes. After all these steps, slides were examined by light microscopy. In a field with high magnification $(\times 400)$, all cells were counted. The area percentage of stained cells was multiplied by the stain intensity and scored as negative/weak, moderate, and strong.

Table 1. Patched-1 immunohistochemistry scoring.

\begin{tabular}{|c|c|c|c|c|c|}
\hline Intensity $\%$ area & $\mathbf{0}$ & 1 & 2 & 3 & 4 \\
\hline 1 & 0 & 1 & 2 & 3 & 4 \\
\hline 2 & 0 & 2 & 4 & 6 & 8 \\
\hline 3 & 0 & 3 & 6 & 9 & 12 \\
\hline
\end{tabular}

Note:

Area percentage of stained cells was scored as:

0 : no expression (no staining)

1 : staining in $1-25 \%$ of the cells

2: staining in $26-50 \%$ of the cells

3: staining in $51-75 \%$ of the cells

4: staining in $76-100 \%$ of the cells

Staining intensity was scored as:

1: weak

2: moderate

3: strong

Final scoring of PTCH1 expression was the result of multiplication of area percentage with staining intensity score and classified as:

Negative/weak: 0-4

Moderate: 5-8

Strong: 9-12

\subsection{Statistical Analysis}

Statistically significant differences and frequency of the PTCH1 expression between the aggressive and nonaggressive BCCs were tested using the chi-squared test in statistical programme for socials sciences (SPSS) version 22.0 with significancy value if $p<0.05$.

\section{Result}

This study was performed on 37 samples of basal cell carcinoma with the largest age distribution of the 60 years and above (54.1\%), whereas under 60 years as many as 17 samples (45.9\%). Subjects in this study consisted of 14 men $(37.8 \%)$ and 23 women $(62.2 \%)$ with a ratio of men versus women was $1: 1.6$.

Table 2 below shows the characteristics of the subjects based on age, gender, and the aggressiveness by histopathology. Total aggressive BCC based on histopathology were 34 samples $(91,9 \%)$ and nonaggressive were 3 samples $(8.1 \%)$.

Table 2. Characteristics of the Sample.

\begin{tabular}{lcc}
\hline Characteristics & n & \% \\
\hline Age & & \\
$<60$ years & 17 & 45.9 \\
>=60 years & 20 & 54.1 \\
$\begin{array}{l}\text { Gender } \\
\text { Male }\end{array}$ & \\
$\begin{array}{l}\text { Female } \\
\text { Histopathologic aggressiveness }\end{array}$ & 37.8 \\
$\begin{array}{l}\text { Aggressive } \\
\text { Nonaggressive }\end{array}$ & 34 & 62.2 \\
\hline
\end{tabular}

In this study, there are 11 histopathologic types. Micronodular is the most common histopathologic type, which is found in 30 of 37 subjects $(81.1 \%)$ and in 30 of 88 histopathological results $(34.1 \%)$. Each subject can have more than one histopathologic feature. Therefore, we were unable to analyze it statistically to assess the correlation between histopathological features and PTCH1 expression. Table 3 shows distribution of histopathologic feature in the samples.
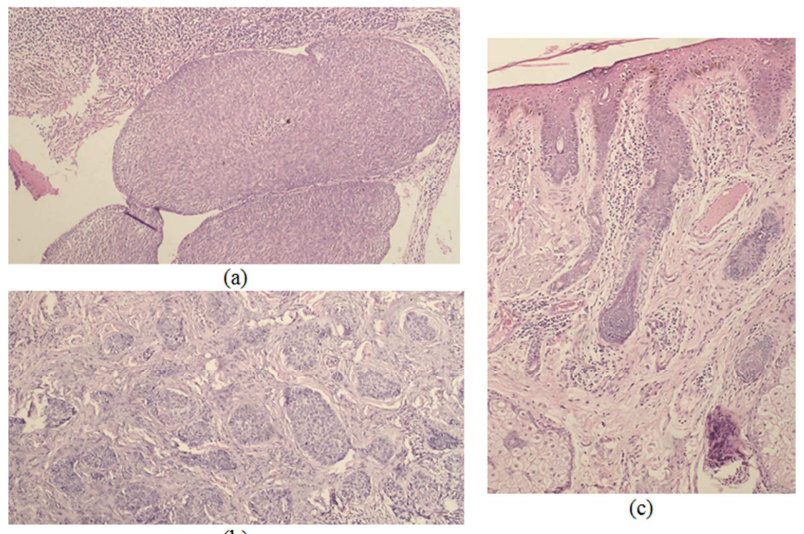

(b)

Figure 1. Histopathologic features of samples: (a) nodular subtype (solid circumscribe); (b) micronodular subtype; (c) infiltrating subtype.

Table 3. Distribution of histopathologic features.

\begin{tabular}{llll}
\hline \multirow{2}{*}{ Histopathologic features } & \multicolumn{2}{l}{ Frequency } & \multirow{2}{*}{$\%$ Case } \\
\cline { 2 - 3 } & $\mathbf{n}$ & $\mathbf{\%}$ & \\
\hline Nodular & 12 & $13.60 \%$ & $32.40 \%$ \\
Micronodular & 30 & $34.10 \%$ & $81.10 \%$ \\
Pigmented & 12 & $13.60 \%$ & $32.40 \%$ \\
Adenoid & 7 & $8.00 \%$ & $18.90 \%$ \\
Infiltrating & 15 & $17.00 \%$ & $40.50 \%$ \\
\hline
\end{tabular}




\begin{tabular}{llll}
\hline \multirow{2}{*}{ Histopathologic features } & \multicolumn{2}{l}{ Frequency } & \multirow{2}{*}{$\%$ Case } \\
\cline { 2 - 3 } & $\mathbf{n}$ & $\mathbf{\%}$ & \\
\hline Infundibulocystic & 1 & $1.10 \%$ & $2.70 \%$ \\
Perineural invasion & 1 & $1.10 \%$ & $2.70 \%$ \\
Basosquamous & 6 & $6.80 \%$ & $16.20 \%$ \\
Metatypical & 1 & $1.10 \%$ & $2.70 \%$ \\
Aggression to cartilage & 1 & $1.10 \%$ & $2.70 \%$ \\
Morpheaform & 2 & $2.30 \%$ & $5.40 \%$ \\
\hline
\end{tabular}

Table 4 below shows the distribution of PTCH1 expression according to the histopathologic features, which is seen that:

- The percentage of strong PTCH1 expression was found highest in pigmented $\mathrm{BCC}(33.4 \%)$ among the other types (the histopathologic feature which is only one or two samples were not taken into account).

- The percentage of moderate PTCH1 expression was found highest in the type of infiltrating BCC $(60.0 \%)$ among the other types (the histopathologic feature which is only one or two samples were not taken into account).

- The percentage expression of negative / weak PTCH1 expression was found highest in the nodular BCC (75.0\%) among the other types (the histopathologic feature which is only one or two samples were not taken into account).

Table 4. Distribution of PTCH1 expression by histopathologic feature.

\begin{tabular}{|c|c|c|c|c|c|}
\hline \multirow{2}{*}{$\begin{array}{l}\text { Histopathologic } \\
\text { features }\end{array}$} & & \multicolumn{3}{|c|}{ PTCH1 expression } & \multirow{2}{*}{ Total } \\
\hline & & Negative/weak & Moderate & Strong & \\
\hline \multirow{2}{*}{ Nodular } & $\mathrm{n}$ & 9 & 1 & 2 & 12 \\
\hline & $\%$ & $75.0 \%$ & $8.3 \%$ & $16.7 \%$ & \\
\hline \multirow{2}{*}{ Micronodular } & $\mathrm{n}$ & 14 & 11 & 5 & 30 \\
\hline & $\%$ & $46.7 \%$ & $36.7 \%$ & $16.7 \%$ & \\
\hline \multirow{2}{*}{ Pigmented } & $\mathrm{n}$ & 3 & 5 & 4 & 12 \\
\hline & $\%$ & $25 \%$ & $41.7 \%$ & $33.3 \%$ & \\
\hline \multirow{2}{*}{ Adenoid } & $\mathrm{n}$ & 4 & 2 & 1 & 7 \\
\hline & $\%$ & $57.1 \%$ & $28.6 \%$ & $14.3 \%$ & \\
\hline \multirow{2}{*}{ Infiltrating } & $\mathrm{n}$ & 4 & 9 & 2 & 15 \\
\hline & $\%$ & $26.7 \%$ & $60.0 \%$ & $13.3 \%$ & \\
\hline \multirow{2}{*}{ Infundibulocystic } & $\mathrm{n}$ & 0 & 0 & 1 & 1 \\
\hline & $\%$ & $0.0 \%$ & $0.0 \%$ & $100.0 \%$ & \\
\hline \multirow{2}{*}{$\begin{array}{l}\text { Perineural } \\
\text { invasion }\end{array}$} & $\mathrm{n}$ & 1 & 0 & 0 & 1 \\
\hline & $\%$ & $100.0 \%$ & $0.0 \%$ & $0.0 \%$ & \\
\hline \multirow{2}{*}{ Basosquamous } & $\mathrm{n}$ & 2 & 2 & 2 & 6 \\
\hline & $\%$ & $33.4 \%$ & $33.3 \%$ & $33.3 \%$ & \\
\hline \multirow{2}{*}{ Metatypical } & $\mathrm{n}$ & 0 & 0 & 1 & 1 \\
\hline & $\%$ & $0.0 \%$ & $0.0 \%$ & $100.0 \%$ & \\
\hline \multirow{2}{*}{$\begin{array}{l}\text { Aggresion to } \\
\text { cartilage }\end{array}$} & $\mathrm{n}$ & 0 & 1 & 0 & 1 \\
\hline & $\%$ & $0.0 \%$ & $100.0 \%$ & $0.0 \%$ & \\
\hline \multirow{2}{*}{ Morpheaform } & $\mathrm{n}$ & 1 & 1 & 0 & 2 \\
\hline & $\%$ & $50.0 \%$ & $50.0 \%$ & $0.0 \%$ & \\
\hline Total & $\mathrm{n}$ & 17 & 14 & 6 & 37 \\
\hline
\end{tabular}

In this study, the correlation between the aggressiveness and PTCH 1 expression was not significant statistically $(p>0.05)$, but it is seen that the frequency of strong PTCH 1 expression are higher in aggressive $\mathrm{BCC}$ than nonaggressive. The frequency of the level of aggressiveness on the expression PTCH1 histopathologic picture can be seen in Table 5.
Table 5. The frequency of the PTCH1 expression in aggressive and nonaggressive $B C C$

\begin{tabular}{llllll}
\hline \multirow{2}{*}{ Aggressiveness } & & \multicolumn{2}{l}{ PTCH1 expression } & \multirow{2}{*}{ Total } \\
\cline { 3 - 5 } & & Negative/weak & Moderate & Strong & \\
\hline \multirow{2}{*}{ Aggressive } & $\mathrm{n}$ & 14 & 14 & 6 & 34 \\
& $\%$ & $41.2 \%$ & $41.2 \%$ & $17.6 \%$ & $100.0 \%$ \\
\multirow{2}{*}{ Nonaggressive } & $\mathrm{n}$ & 3 & 0 & 0 & 3 \\
& $\%$ & $100.0 \%$ & $0.0 \%$ & $0.0 \%$ & $100.0 \%$ \\
\multirow{2}{*}{ Total } & $\mathrm{n}$ & 17 & 14 & 6 & 37 \\
& $\%$ & $45.9 \%$ & $37.8 \%$ & $16.2 \%$ & $100.0 \%$ \\
\hline
\end{tabular}

Chi Square $(\mathrm{p}=0.099)$

In addition, we did the linear regression analysis between the variables of gender, age, and aggressiveness by histopathology with PTCH1 expression to quantify the strength of the relationship between multiple variables with the PTCH1 expression, where it appears that the value of B is the strength of correlation of each variable on the expression PTCH1, although it is not significant $(p>0.05)$. The magnitude of the combined strength of all variables on the expression PTCH1 $\left(R^{2}\right)$ was $11.0 \%$ (Table 6). The aggressiveness of $\mathrm{BCC}$ was strongly correlated with the expression PTCH1 $(\mathrm{B}>0.75)$ in which the more aggressive the histopathologic type, the stronger the PTCH1 expression.

Table 6. Analysis of linear regression of the variables gender, age, and aggressiveness with PTCH1 expression.

\begin{tabular}{llll}
\hline Variable & B & p-value & Confidence interval \\
\hline Gender & -0.018 & 0.943 & $-0.537-0.500$ \\
$\begin{array}{l}\text { Age } \\
\begin{array}{l}\text { Aggressiveness of BCC } \\
\text { histopathology }\end{array}\end{array}$ & 0.243 & 0.322 & $-0.249-0.736$ \\
\hline
\end{tabular}

$\mathrm{R}^{2}=0.110$

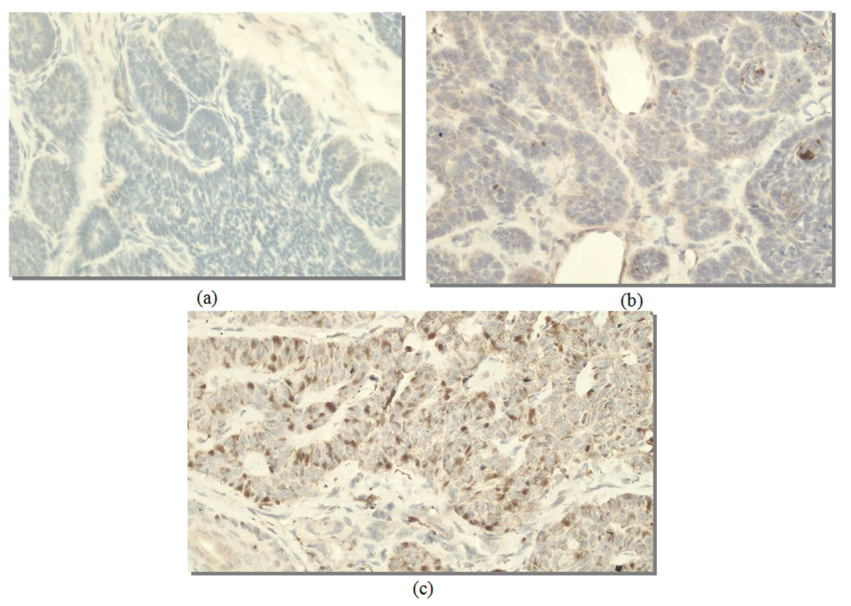

Figure 2. Immunohistochemistry staining of PTCH1: (a) weak expression; (b) moderate expression; (c) strong expression.

\section{Discussion}

Basal cell carcinoma (BCC) is the most common human malignancy, amounting to $90 \%$ of skin cancers. Risk factors for BCC include fair skin type, sun exposure, ionizing radiation, advanced age, immunosuppression, and a personal history of nonmelanoma skin cancer. [16] In this study we 
found the most age distribution was 60 years old and above. This is according to a meta-analysis performed by Marcil and Stern of the 7 studies that found a significant predictor factor of the high incidence of BCC is age over 60 years. [17]

Specifically, ultraviolet (UV) and ionizing radiation can induce DNA damage that leads to the development of skin cancer, and defective DNA repair is associated with advanced age. [16] The pattern of the age-specific incidence rates for nodular BCC is showed a progressive and dramatic increase with age in both men and women, support previous speculation that the nodular subtype is more related to chronic cumulative sun exposure (similar to SCC). [18] In addtion, the previous studies concluded that the development of BCC occurs in a period of 10 to 50 years after sun damage. Basal cell carcinoma usually develops as a benign tumor, with slow growth and takes more than six months to reach $1 \mathrm{~cm}$, The average duration of the lesion from the onset to diagnosis of 37.1 months for men and women. [19]

The women in this study were more than men with a ratio of 1.6: 1. Based on studies conducted by Lesiak et al, recently there is a significant increase of the incidence of BCC, especially among women. [20] According to Abbas and Borman, this was caused by changes in fashion over the development of lifestyle. [21] In addition, women are also more concerned about his appearance so that the level of awareness for the treatment and to check themselves is higher than men.

In this study, the most type of BCC based on histopathological features we found were aggressive BCCs $(91.9 \%)$. This is likely due to the patient as a new laity checked himself into the hospital if the condition of the disease has lasted a long time and felt intrusive. In addition, the study was conducted in referral hospitals so that the patients who come mostly in the form of advanced cases. This is consistent with research in various referral centers by Vico $\mathrm{P}$ et al, Leffell D et al, and Brown $\mathrm{C}$ et al who reported the frequency of histopathologic feature of BCC aggressive ranged from 2.5 to $44 \%$. The patient's age and histology pattern does not appear to correlate significantly. [1]

Inactivation of patched (PTCH1) as a "gate keeper" in BCCs may be necessary, if not sufficient, event for carcinogenesis. The majority of neoplasms, both sporadic and hereditary, show allelic loss for chromosome 9q22. [22]. In conditions where PTCH1 are not functional, smoothened (SMO) become activated out of hedgehog control, and can induce overexpression of target genes including PTCH1. [23] This overexpression has mitogenic effect and causes tumor growth.

In this study, the correlation between the aggressiveness and PTCH 1 expression was not significant statistically ( $p>0.05$ ), but it is seen that the frequency of strong PTCH 1 expression was higher in aggressive BCC and all nonaggressive BCC showed negative / weak expression. Insufficient number of samples caused this result is not significant statistically and less able to represent the general population. However, from the linear regression analysis it appears that the level of aggressiveness strongly correlate with the expression PTCH1 $(\mathrm{B}>0.75)$ in which the more aggressive the histopathology the stronger the expression PTCH1. Study by Fernandes et al found that $100 \%$ BCC aggressive encountered loss of heterozygosity (LOH) at chromosome $9 \mathrm{q} 22$ compared to $13.3 \%$ in nonaggressive BCC $(p=0.003)$. From these findings, Fernandes et al raised the possibility of mutations in PTCH accompanied by loss or allelic imbalance can be the deciding factor of $\mathrm{BCC}$ development, where the $\mathrm{LOH}$ is more indicative for the aggressiveness of the tumor. [13] Study by Agren et al found an increased expression of the exon 1B isoforms of PTCH1 gene in nodular BCC. [24]

In Table 5 it is seen that the negative / weak PTCH1 expression were also found in $41.2 \%$ aggressive BCC. This is likely to be caused by a mutation that occurred was not involving PTCH1 protein, but mutations of other genes, one of the most common is p53. In addition, we also suggest that this is can be caused by nonsense mutation or frameshift mutation of PTCH1 gene so that the protein produced is not fully formed, not functional, or into other proteins. Study by Azterbaum et al (1998) found that mutations most commonly found in patients with sporadic BCC and basal cell nevus syndrome, is a frameshift mutation in PTCH1 exon. [25] A recent study by Skodric-Trifunovic et al (2015) found a frameshift mutation in exon 6 PTCH1 gene and nonsense mutations in exon 8 PTCH1 genes. [26]

In Table 5 it appears that the frequency of strong PTCH1 expression was found mostly in pigmented subtype, moderate expression in infiltrating subtype, and negative / weak expressions in the nodular subtype. Paired studies by Hendrix et al on 278 infiltrating and nodular BCC found that infiltrative subtype was more destructive and difficult to detect. [27] Infiltrative tumors have a higher growth fraction assessed by immunohistochemistry using the Ki-67 [28]. Strong PTCH1 expression was mostly found in pigmented subtype, is likely to be caused by the melanin pigment which absorbs PTCH1 antibody staining and showed the brown color more dominant than basal cells in the tumor nests.

According to Kaur (2006) BCC aggressiveness is the result of normal epithelial transition to benign tumors and malignant tumors and its development in biomechanical and biochemical via multiple genetic signaling pathways. [29] Until recently, there has been no agreement and still any differences in opinion, about the gene marker as the gold standard in determining BCC will become progressive. Several studies had been conducted previously in various genetic molecules to find a marker for aggressive BCC. Previous immunohistochemistry study on BCC showed an increased expression of hyaluronan, Ki-67 and proliferating cell nuclear antigen (PCNA) as a stromal reaction in infiltrative $\mathrm{BCC}$ than in nodular $\mathrm{BCC}$, this study proved that those increase in three biological molecules is an indication of invasive $\mathrm{BCC}$ and can be used as the treatment strategy. [30]

Other research by Haskell (2005) which evaluated the immunohistochemistry on the morpheaform and infiltrative subtype, showed a significant correlation between increased 
expression of $\beta$ catenin and the aggressive histopathological feature of BCC. [31] Adegboyega (2010) proved that there was significant relationship between increased expression of $\alpha$-smooth muscle actin ( $\alpha \mathrm{SMA}$ ) and the aggressive histopathological feature of BCC. [32] Study by Yahya (2010) proved an increased expression of $\beta$-catenin and $\alpha 6$ $\beta 4$ integrin in aggressive histopathological type of $\mathrm{BCC}$ using immunohistochemistry. [33]

This study showed that the strong PTCH1 expression was found higher in aggressive type of BCC and had a strong correlation, but because the sample number is small, the correlation was not significant. Further research is still needed with a larger number of samples to ensure the correlation between the expression of PTCH1 protein and the aggressiveness of BCC.

\section{Conclusion}

In this study, the correlation between the aggressiveness and PTCH1 expression was not significant statistically $(\mathrm{p}>0.05)$, but it is seen that the frequency of strong PTCH1 expression was found to be higher in aggressive than nonaggressive $\mathrm{BCC}$. The strong PTCH1 expression was found highest in pigmented $\mathrm{BCC}$, moderate expression was found highest in infiltrating $\mathrm{BCC}$, and negative/weak expression was found highest in nodular BCC. Therefore, we may suggest that PTCH1 protein may predict the aggressiveness of BCC.

\section{References}

[1] Walling, H. W., et al., Aggressive basal cell carcinoma: Presentation, pathogenesis, and management. Cancer Metastasis Rev, 2004. 23: p. 389-402.

[2] Sordo, R. D., A. Cavaliere, and A. Sidoni, Basal Cell Carcinoma With Matrical Differentiation: Expression of.catenin and Osteopontin. Am J Dermatopathol, 2007. 29: p. $470-4$.

[3] Rubin, A. I., E. H. Chen, and D. Ratner, Current Concepts Basal-Cell Carcinoma. NEJM, 2005. 353: p. 2262-9.

[4] Leon, A., et al., Assessment of the aggressive feature of basal cell carcinoma in the oral and maxillofacial region. OHDMBSC, 2006. 5 (4): p. 62-67.

[5] Tilli, C. M. L. J., et al., Molecular aetiology and pathogenesis of basal cell carcinoma. Br J Dermatol, 2005. 152: p. 1108-24.

[6] Goppner, D. and M. Leverkus, Basal Cell Carcinoma: From the Molecular Understanding of the Pathogenesis to Targeted Therapy of Progressive Disease. J Skin Cancer, 2011. 2011: p. 650258 .

[7] Zwaan, S. E. d. and N. K. Haass, Genetics of basal cell carcinoma. Australas J Dermatol, 2010. 51: p. 81-94.

[8] Yahya, Y. F., et al., Profil Karsinoma Sel Basal Primer di RSUP M. Hoesin Palembang. MDVI, 2011.38 (2): p. 78-83.

[9] Marcelina, P., et al., Profil Karsinoma Sel Basal di Unit Rawat Jalan Ilmu Kesehatan Kulit dan Kelamin RSUP Dr. Wahidin
Sudirohusodo Makassar Tahun 2010-2014, 2014, Departemen Ilmu Kesehatan Kulit dan Kelamin Fakultas Kedokteran Universitas Hasanuddin: Makassar. p. 1-20.

[10] Tang, J. Y., P.-L. So, and E. H. Epstein, Novel Hedgehog pathway targets against Basal Cell Carcinoma. Toxicol Appl Pharmacol, 2007. 224 (3): p. 257-64.

[11] Crowson, A. N., Basal cell carcinoma: biology, morphology and clinical implications. Mod Pathol, 2006. 19: p. S127S147.

[12] Mizuno, T., et al., Molecular basis of basal cell carcinogenesis in the atomic-bomb survivor population: p53 and PTCH gene alterations. Carcinogenesis, 2006. 27 (11): p. 2286-94.

[13] Fernandes, H., et al., Molecular signatures linked with aggressive behavior in basal cell carcinoma: a report of 6 cases. Am J Dermatopathol, 2010. 32 (6): p. 550-6.

[14] Lesiak, A., et al., Sonic hedgehog pathway dysregulation in skin basal-cell carcinoma of a Polish population. Folia Histochemica et Cytobiologica, 2013. 51 (3): p. 219-24.

[15] Tojo, M., et al., Expression of sonic hedgehog signal transducers, patched and smoothened, in human basal cell carcinoma. Pathol Int, 1999. 49: p. 687-94.

[16] Iwasaki, J. K., et al., The molecular genetics underlying basal cell carcinoma pathogenesis and links to targeted therapeutics. J Am Acad Dermatol, 2012. 66: p. e167-78.

[17] Marcil, I. and R. S. Stern, Risk of developing a subsequent nonmelanoma skin cancer in patients with a history of nonmelanoma skin cancer: a critical review of the literature and meta-analysis. Arch Dermatol 2000. 136: p. 1524-30.

[18] Raasch, B., P. Buettner, and C. Garbe, Basal cell carcinoma histological classification and body-site distribution. $\mathrm{Br} \mathrm{J}$ Dermatol, 2006. 155: p. 401-7.

[19] Chinem, V. P. and H. A. Miot, Epidemiology of basal cell carcinoma. An Bras Dermatol, 2011. 86 (2): p. 292-305.

[20] Lesiak, A., et al., Risk factors in Central Poland for the development of superficial and nodular basal cell carcinomas. Arch Med Sci, 2010. 6: p. 270-5.

[21] Abbas, O. L. and H. Borman, Basal Cell Carcinoma: A Single-Center Experience. ISRN Dermatology, 2012. 2012: p. $1-6$.

[22] Gailani, M. R. and A. E. Bale, Developmental Genes and Cancer: Role of Patched in Basal Cell Carcinoma of the Skin. J Natl Cancer Inst 1997. 89: p. 1103-9.

[23] Stone, D. M., et al., The tumour-suppressor gene patched encodes a candidate receptor for Sonic hedgehog. Nature, 1996. 384: p. 129-34.

[24] Agren, M., et al., Expression of the PTCH1 tumor suppressor gene is regulated by alternative promoters and a single functional Gli-binding site. Gene, 2004. 330: p. 101-14.

[25] Azterbaum, M., et al., Identification of mutations in human PATCHED gene in sporadic basal cell carcinomas and in patients with the basal cell nevus syndrome. J Invest Dermatol, 1998. 110: p. 885-8.

[26] Škodrić-Trifunović, V., et al., Novel Patched 1 mutations in patients with nevoid basal cell carcinoma syndrome - case report. Croat Med J, 2015. 56: p. 63-7. 
[27] Hendrix, J. J. and H. L. Parlette, Duplicitous growth of infiltrative basal cell carcinoma: Analysis of clinically undetected tumor extent in a paired case control study. Dermatol Surg, 1996. 22: p. 535-9.

[28] Horlock, N., et al., Cellular proliferation characteristics do not account for the behavior of horrifying basal cell carcinoma. A comparison of the growth fraction of horrifying and nonhorrifying tumors. Brit J Plast Surg, 1998. 51: p. 59-66.

[29] Kaur, P., M. Mulvaney, and J. A. Carlson, Basal cell carcinoma progression correlates with host immune response and stromal alternations; a histologic analysis. Am J Dermatopathol, 2006. 28 (4): p. 293-306.

[30] Bertheima, U., et al., The stromal reaction in basal cell carcinomas. A prerequisite for tumour progression and treatment strategy. Br Plastic Surgeons, 2004. 57: p. 429-39.

[31] Haskell, H. D., et al., Basal cell carcinoma with matrical differentiation: a case study with analysis of betacatenin. J Cutan Pathol, 2005. 32 (5): p. 245-50.

[32] Adegboyega, P. A., S. Rodriguez, and S. J. McLarty, Stromal expression of actin is a marker of aggressiveness in basal cell carcinoma. Human Pathology, 2010. 41: p. 1128-37.

[33] Yahya, Y. F., et al., Ekspresi $\beta$ catenin dan $\beta 4$ integrin pada karsinoma sel basal agresif dan non agresif, in Disertasi Program Pascasarjana, Universitas Airlangga, Surabaya, Indonesia. 2010. 